\title{
Immediate recall as a secondary text: Referential parameters, pragmatics and propositions
}

\author{
Anna A. PETROVA and Marina I. SOLNYSHKINA \\ Kazan (Volga Region) Federal University \\ Kazan, Russia
}

\begin{abstract}
Since the process of recalling combines comprehension and speech production, it is viewed as an extremely complex though understudied linguo-cognitive phenomenon. Recalls as secondary texts or text derivatives are also considered to be a good material to explore cognitive aspects of secondary texts production, information conversion procedures and types of transformations of primary texts. The notion of 'secondary texts' also implies multiplicity, as an original text may be retranslated into numerous secondary texts different in quality and degree of completeness. The purpose of the study is to model the propositional secondary retold texts and to identify the specifics of the recipients' interpretation of the main event in the text. It is aimed at discriminating the differences between the primary expository text and its 134 immediate recalls produced by 15 -year old native Russian speakers. In order to reveal the specifics of the propositional content of a primary expository text and its recalls, their recipients used the following methodological operations: the description and interpretation of the semantic roles of the first and second arguments aligned to predicates on the basis of the verbs' semantic properties; the employment of the psycholinguistic model of the utterances generation; the characteristic of memory as a complex of cognitive and mnemic processes; the definition of cognitive-semantic discourse structures; and the understanding of a proposition as a stable component of an utterance independent of the surface grammar. The comparison of the original text and its recalls with the use of innovative "denotative maps" enabled us to define successful and unsuccessful expression of propositional structures and the main idea of the original text. The classification of texts includes four groups based on the number of the reproduced propositions and types (weak or successful) of the reflection of the primary text denotative card. The authors designed and successfully implemented an innovative 11 stagealgorithm of revealing patterns of a printed text comprehension and its immediate recalls including the primary visual perception of the text, its primary interpretation, reading, encoding, reflection, preparation for an oral presentation, desobjectivation (distribution of semantic roles), interpretation, reflection, oral implementation and text. The work fills in certain gaps in the research, such as the specifics of immediate recalls production, identification of changes in propositional structures of immediate recalls, and expanding the corpus of semantic roles similar to Frame Net. The findings can be successfully applied in natural language processing and linguistic didactics.
\end{abstract}

Keywords: immediate recalls, recipient, denotative map, proposition, natural language processing

For citation:

Petrova, Anna A. \& Marina I. Solnyshkina. 2021. Immediate recall as a secondary text: Referential parameters, pragmatics and propositions. Russian Journal of Linguistics 25 (1). 221-249. DOI: $10.22363 / 2687-0088-2021-25-1-221-249$ 


\title{
Неподготовленный устный пересказ как вторичный текст: референциально прагматические и пропозициональные характеристики
}

\author{
А.А. ПЕТРОВА, М.И. СОЛНЫШКИНА \\ Казанский (Приволжский) федеральный университет \\ Казань, Россия
}

\begin{abstract}
Аннотация
Пересказ, или текст-дериват, объединяя в себе восприятие и порождение речи, является малоизученным и чрезвычайно сложным лингвокогнитивным феноменом, позволяющим обратиться к когнитивным особенностям порождения вторичных текстов, способам преобразования информации, а также к типам трансформаций первичного текста. Вторичность является общим свойством любых текстов-дериватов и представляет собой признак, по которому тексты-дериваты различаются между собой. Из этого следует, что от одного первичного текста может быть образовано множество вторичных текстов, представляющих с разным качеством и степенью полноты первичный текст. Предлагаемая работа посвящена изучению соотношения первичного письменного текста и его деривата - вторичного устного текстапересказа. Цель работы состоит в моделировании пропозиционального содержания вторичных текстов-пересказов и выявлении специфики интерпретации главного события текста его реципиентами. В качестве материала использованы учебный текст-оригинал и 134 текстапересказа, выполненных носителями русского языка. Для выявления специфики пропозиционального содержания вторичных текстов-пересказов и интерпретации главного события текста его реципиентами были использованы следующие методологические операции: описание семантических ролей и интерпретация первого и второго аргументов с позиций семантики предиката; применение концепции психолингвистической модели порождения высказывания; характеристика функционирования памяти как сложного познавательного и мнемического процесса, определение когнитивно-семантических структур актуального дискурса, понимание пропозиции как стабильного компонента, не зависящего от состава поверхностной структуры высказывания. Тексты оригинала и пересказов сравнивались на основе разработанных денотативных карт в зависимости от успешности передачи пропозициональных структур и основной идеи текста-оригинала. Классификация текстов включает четыре группы пересказов в зависимости от количества воспроизведенных пропозиций и типов (слабое/успешное) отображений денотативной карты первичного текста. Новаторским является предлагаемый авторами алгоритм изучения этапов и закономерностей смыслового восприятия письменного текста и его устного воспроизведения, включающий 11 этапов: первичное визуальное восприятие, первичная интерпретация, чтение, кодирование, рефлексия, подготовка к устному изложению, распредмечивающее понимание, интерпретация, рефлексия, устная реализация, текст. Работа заполняет ряд исследовательских ниш, таких как специфика порождения вторичных текстов, выявление метаморфоз пропозициональных структур неподготовленных пересказов, расширение эмпирической базы корпусных исследований в области составления словарей семантических ролей типа FrameNet, и может найти практическое применение в автоматической обработке текстов и лингводидактике.
\end{abstract}

Ключевые слова: неподготовленный текст, рециипент, денотативная карта, пропозиция, обработка естественно-языковых текстов 


\section{Для цитирования:}

Петрова А.А., Солнышкина М.И. Неподготовленный устный пересказ как вторичный текст: референциально прагматические и пропозициональные характеристики. Russian Journal of Linguistics. 2021. T. 25. № 1. C. 221-249. DOI: 10.22363/2687-00882021-25-1-221-249

\section{1. Введение}

Тема работы связана с изучением процесса порождения вторичных устных текстов, трактуемого в настоящем исследовании как создание одного текста на базе другого. Вторичными являются тексты, порождаемые в результате различных мнемических и ментальных фаз аналитико-синтетической обработки исходных первичных текстов. В качестве рабочей выступила гипотеза о том, что в процессе устного пересказа письменного текста, т.е. создания вторичного текста, наблюдается ряд когнитивных процессов, способствующих полной или частичной реструктуризации пропозиций первичного текста. При этом продукт устного пересказа обнаруживает семантические добавления, упрощения или смещения, находящие отражение как в глубинных связях актантно-предикатных составляющих пропозиций, так и в самом количестве пропозиций.

Цель работы состоит в моделировании пропозиционального содержания вторичных текстов-пересказов и выявлении специфики интерпретации главного события текста его реципиентами.

Реализация данной цели предполагает решение следующих задач: 1) моделирование денотативной структуры письменного исходного учебного текста и аналогичных структур устных вторичных текстов-пересказов; 2) моделирование глобальных пропозиций (макропропозиций), репрезентирующих макроситуации, и пропозиций, репрезентирующих микроситуации исходного и вторичных текстов; 3) сопоставление макропропозиций и пропозиций исходного и вторичных текстов; 4) выявление вариантов несоответствий (утрата или добавление атомарных пропозиций, трансформация элементов пропозиций, трансформация эксплицитных макропропозиций, фиксация замещающих и замещаемых пропозиций) пропозициональных структур письменного исходного учебного текста пропозициональным структурам устного текста-репродуктива.

«Несоответствия» могут проявляться в следующем: а) дискретизация устной речи осуществляется благодаря сознательной (мыслительной) деятельности человека, в процессе которой непрерывная устная речь сегментируется и соотносится с лингвистическими и содержательными представлениями; б) содержательная информация в устной речи образуется непрерывно, часто без постоянного контроля со стороны говорящего, и отличается неорганизованностью в деталях, незавершенностью и непостоянством, которые компенсируются акцентно-интонационным переструктурированием, автокоррекцией, интервалами в звучании, переинтерпретациями и оговорками; 
в) письменная речь, напротив, пространственно-линейно организована, кодифицирована и нормирована, подвержена предварительному обдумыванию, планированию и коррекции, логична построена; г) устный пересказ как феномен устной речи подвержен ее закономерностям (Земская 2004).

\section{2. Восприятие первичных текстов и порождение вторичных текстов как объекты исследований разных областей знания}

Проблема порождения вторичных текстов сопряжена с проблемой порождения речи, восходит к генеративной грамматике Н. Хомского (Chomsky 1969, Chomsky 1986) и, благодаря многолетним теоретическим и практическим изысканиям, приобретает новый ракурс и смысл. В настоящее время изучается реальный механизм протекания речевой деятельности как процесса, связанного с восприятием речи (оформленной в виде письменного текста или озвученной вслух) и созданием речевого высказывания (в письменной или устной форме), т.е. от его истоков в мыслительной деятельности человека до завершающих стадий оформления мысли в слове и передачи ее в целом тексте.

Этапам и закономерностям восприятия текста, а также видам его пересказа (письменным или устным) посвящено большое количество исследований из разных, часто смежных областей знания: психологии, психолингвистики, лингвистики, когнитологии, герменевтики (Богин 2001, Голев 1989, Дейк, Кинч 1988, Дейк 1989, Дридзе 2000, Жинкин 1982, Земская 2004, Зимняя 2001, Исенбаева 2009, Клюев 2002, Леонтьев 2005, Леонтьев 2007, Мустайоки 2006, Новиков 1983, Петрова, Солнышкина 2019, Сахарный 1989, Chomsky 1969, Chomsky 1986, Fillmore 1968, Fillmore 1977, Fillmore 1982, Friederici 1995, Lyashevskay, Kashkin 2015, Mustajoki 2012, Petrova, Rebrina 2016 и др.).

Отправной точной преимущественного большинства вышеуказанных исследований является обращение к когнитивным процессам реципиентов, таким как интерпретация, понимание и осмысление процессов референции, концептуализации и категоризации реальных и мыслимых объектов, предикативности и пропозициональности, запоминания и извлечения из памяти, в том числе в онтогенетическом плане (см. Petrova, Rebrina 2016), объективизации замысла в процессе формирования и формулирования мысли посредством языка.

Тем не менее, выделяя общий терминологический аппарат, следует признать, что подходы к проблемам восприятия текста у выделенных областей знания различны, и связано это в большей степени с отношением к языку, с включением языка в объект исследования восприятия текста. Так, одна часть исследователей склоняется к герменевтическому подходу, к моделям восприятия текста (Богин 2001, Дридзе 2000, Шелестюк 2010), в то время как другая часть работает в рамках психолингвистического направления изучения восприятия текста (Жинкин 1982, Зимняя 2001, Леонтьев 2005, Леонтьев 2007). 
Как отмечают ученые, занимающиеся проблемами герменевтики, герменевтику трудно излагать в герменевтических терминах, но попытки объяснить ее в прагматическом ключе применительно к проблемам порождения текста, первичности и вторичности текстов приводят к мысли о ее близости психолингвистическим феноменам, таким как «связность и цельность текста» (Сахарный 1989: 121). При этом синтагматическая природа связности, заложенная в определенных способах и средствах, реализует в сукцессивной структуре текста его симультанную цельность. Такое соотношение связности $=$ сукцессивности и цельности $=$ симультанности приводит Л.В. Сахарного (Сахарный 1989) к идее о существовании в языковой способности человека «номиноцентрической» (симультанной = цельной с минимумом специальных средств связанности) и «предикатоцентрической» (сукцессивной, обеспечивающей построение развернутых связных текстов) грамматик. Последняя «обладает достаточно мощным аппаратом специальных средств связности (преимущественно средств трансформационных преобразований) для организации текста» (Сахарный 1989: 146). В аспекте нашего исследования значимым, полагаем, является то, что именно данные грамматики участвуют в пропозициональном структурировании первичных и вторичных текстов по принципу процедур свертывания (макропропозиции: Дейк, Кинч 1988, Дейк 1989) и развертывания (главные и субпропозиции: Мустайоки 2006, Fillmore 1968, Fillmore 1977, Fillmore 1982, Lyashevskay, Kashkin 2015) семантических вех текста. Такой подход позволяет выделить в макропропозиции ее цельность и симультанность, а в пропозициях - связность и сукцессивность. Существенным в аспекте изучения динамики порождения вторичного текста в процессе понимания исходного текста является использование содержания понятия номинации, которое сопряжено с понятием текста. В основе образования номинации и текста лежит один и тот же механизм предицирование. «Оба представляют собой и процесс, и результат речевой деятельности, однако, номинация в большей степени результативна, а текст в большей степени процессуален, следовательно, номинация тяготеет к свертыванию, тогда как текст - к развертыванию. При всем различии текста и номинации они предполагают друг друга» (Исенбаева 2009: 60).

В психолингвистике «текст трактуется не как «жесткая» двусторонняя единица с четко зафиксированными планом выражения и планом содержания, а как особым образом организованная форма, связанная с содержанием, от предельно обобщенного, фиксирующего некоторое содержание, до разных по степени детализации возможных интерпретаций этого содержания» (Сахарный 1989: 123).

При оценке восприятия, понимания первичных текстов и их интерпретации, а также при оценке порождения вторичных текстов мы придерживаемся интегративного подхода, базирующегося на единой теории психических процессов: восприятие невозможно без памяти, запоминание невозможно без 
восприятия, а внимание невозможно без мышления, которое, по Л.С. Выготскому (Выготский 1982: 307), «совершается» в слове и, таким образом, связано с лингвистикой.

Согласно лингвистике текста и деривационной текстологии, формированию замысла текста-деривата предшествует осмысление другого («чужого») текста, которое ориентируется на последующее выражение осмысленного в соответствии с жанром первичного текста-оригинала. Вторичность, являясь общим свойством любых текстов-дериватов, представляет собой одновременно признак, по которому тексты-дериваты различаются между собой. Из этого следует, что от одного первичного текста может быть образовано множество вторичных текстов, представляющих с разным качеством и степенью полноты первичный текст (см. Петрова, Солнышкина 2019: 278). Этот аспект проявляется наиболее ярко, если в отношения вступают первичный письменный текст и его дериват - вторичный устный текст-пересказ. Следует отметить, что основная масса работ в области восприятия и порождения речи исследует письменную форму вторичного текста (сочинения, рефераты, резюме) и лишь единицы изучают устные ретрансляты (Куканова 2008, Грудева, Губушкина 2020).

Именно данной проблеме посвящено настоящее исследование, результаты которого позволят уточнить понимание вторичных текстов, порожденных в рамках сценария неподготовленного пересказа, выявить метаморфозы их пропозициональных структур, расширить эмпирическую базу корпусных исследований в области составления словарей семантических ролей и конструкций, синтаксических словарей типа FrameNet-ориентированных ресурсов (Framenet), а также найти практическое применение в автоматической обработке текстов и лингводидактике.

Концепция работы базируется на следующих положениях.

1) В ряде научных направлений, изучающих семантическую структуру предложения, прослеживается стремление описать компоненты семантической структуры: предикаты, актанты, сирконстанты (А. Мустайоки, Е.В. Падучева, Н.Ю. Шведова и др.); описать только объективное содержание предложений (пропозиции), выявить типы пропозиций (Т.Б. Алисова, Т.П. Ломтев, О.И. Москальская и др.); описать не только объективное, но и субъективное содержание предложения: диктум и модус (Н.Д. Арутюнова, Т.В. Шмелева и др.). Обобщив наблюдения в рамках данных направлений, мы используем инвентарь семантических ролей, разработанных для русского языка Е.В. Кашкиным и О.Н. Ляшевской (Кашкин, Ляшевская 2013: 334) при создании системы FrameBank, и исходим из следующих принципов: интерпретация первого и второго аргумента с позиций семантики предиката; построение объема роли с учетом прототипа и периферии; существование сдвоенных ролей и их расщепление.

2) При анализе порождения устного текста-пересказа мы исходим из психолингвистической модели порождения высказывания И.А. Зимней (Зимняя 
2001). Данная модель не противоречит другим моделям (А.А. Леонтьев, Т.В. Ахутина), но уточняет их. По концепции И.А. Зимней, формирующий уровень речепроизводства, осуществляемый фазами смыслообразования и формулирования, одновременно актуализирует механизм выбора слов, механизм временной развертки и артикуляционную программу; последняя объективирует замысел в процессе формирования и формулирования мысли посредством языка.

3) Устная реализация неподготовленного текста-пересказа связана с функционированием памяти как сложного познавательного или мнемического процесса, включающего запоминание, сохранение, воспроизведение и забывание и сопровождающегося мнемическими переживаниями (В.И. Еременко, В.В. Нуркова, К.Н. Василевская). При этом «мнемические переживания взаимосвязаны с характеристиками мнемической продукции, даны субъекту в сознании, могут быть отрефлексированы и выражены в интерактивном поведении реципиента, они могут характеризоваться уровнем тревожности, наличием или отсутствием чувства уверенности, степенью когнитивной переработки материала, наличием или отсутствием эмоционального компонента, активностью поиска информации в памяти» (Еременко 2007: 8, 17, Elosúa, García-Madruga, Vila, Gómez-Veiga \& Gil 2013).

4) Характер когнитивно-семантических структур актуального дискурса и их взаимодействие детерминированы общей прагматикой текста и целеполаганием (Арутюнова 1973, Арутюнова 1982, Гусаренко 2015, Гусаренко 2016, Гусаренко 2017, Клюев 2002, Падучева 2010). При построении модели актуального дискурса основополагающим является положение о том, что пропозиция есть стабильный, неизбежно присутствующий компонент, не зависящий от состава поверхностной структуры высказывания, образуемый при когнитивной обработке высказывания. Из этого следует, что «для более глубокого понимания процедур оперативной обработки речевых произведений необходимо в первую очередь рассматривать взаимодействие пропозиции с другими когнитивно-семантическими структурами, участвующими в когнитивной обработке высказывания» (Гусаренко 2015: 163).

\section{3. Материал и методология}

Итак, основными в исследовании выступали следующие методологические операции: описание семантических ролей и интерпретация первого и второго аргументов с позиций семантики предиката; применение концепции психолингвистической модели порождения высказывания; характеристика функционирования памяти как сложного познавательного и мнемического процесса, определение когнитивно-семантических структур актуального дискурса, представление пропозиции как стабильного компонента, не зависящего от состава поверхностной структуры высказывания.

Условия проведения эксперимента. 134 реципиентам, 15-летним учащимся 9-х классов общеобразовательных школ, носителям русского языка, 
был предложен учебный текст для ознакомительного чтения с бумажного носителя. Источником текста послужил учебник Л.Н. Боголюбова «Обществознание. 10 класс» (Боголюбов 2009). Время чтения не ограничивалось, но не превысило 4 мин. Объем текста составил 252 слова.

В ходе предварительного этапа исследования было осуществлено психолого-лингвистическое тестирование респондентов, включающее следующие тесты: субтест на общую осведомленность, тест Векслера (WISC) ${ }^{1}$, тест на тревожность ${ }^{2}$ и тест на владение русским языком (McCarthy, McNamara, Solnyshkina, Tarasova \& Kupriyanov 2019). По результатам тестирования была сформирована группа из 134 респондентов с приблизительно одинаковым уровнем осведомленности (12-17 баллов), тревожности (17-25), владения русским языком (4-6). Такая схема отбора респондентов обеспечила присутствие в выборке представителей типической группы изучаемой генеральной совокупности респондентов - школьников 9-го класса.

Для обозначения устного текста пересказа мы применяем в качестве синонимов следующие термины: вторичный текст, текст-пересказ, текстреконструкция, репродуктив, ретранслят, репродукт, дериват (деривационная текстология: как образование текста (Т-2) от текста (Т-1)). При этом вторичный текст взаимодействует с первичным текстом по принципу первичности/ вторичности, исходности/производности, простоты/сложности (Голев 1989).

На первом этапе исследования при определении количества и состава пропозиций первичного текста была предпринята попытка интегрировать несколько научных подходов и методик, а именно дискурсивный подход (Дейк 1989), метод семантического анализа, основными понятиями которого являются «пропозиция» и «база текста», денотативный анализ (Бабенко, Казарин 2005, Дейк, Кинч 1988, Дейк 1989, Новиков 1983), а также анализ семантической структуры высказываний в текстах-пересказах. Результатом интеграции стала пропозициональная модель денотативной структуры текста, основанная на вычленении внутренней структуры пропозиции, детерминируемой числом и характером составляющих ее элементов, т.е. актантов (субъект, объект, адресат, инструмент) и сирконстантов (обстоятельств: локатив (место); темпоратив (время)) (Мустайоки 2006, Fillmore 1968, Fillmore 1977, Fillmore 1982, Lyashevskay, Kashkin 2015). При этом облигаторным для понимания, по мнению Т.А. ван Дейка, является «создание носителем языка семантического представления дискурса в форме базы текста, состоящей из локально и глобально связанной последовательности пропозиций» (Дейк 1989: 73). Пропозиция в рамках данного подхода рассматривается как семантический инвариант, стабильное семантическое ядро и представляет «интеллектуальную модель ситуации» (Шмелева 1983: 43). Иными словами, пропозиция - это

${ }^{1}$ Тест интеллекта Векслера / детский вариант (6,5-16,5 лет) [Электронный ресурс]. URL: https://www.dbglab.ru/slovar-dannykh/221/ (дата обращения: 24.01.2021).

${ }^{2}$ Интегративный тест тревожности [Электронный pecypc]. URL: https://psylab.info/ Интегративный_тест_тревожности (дата обращения: 24.01.2021). 
языковой аналог ситуации, вербализованная модель ситуации как факта экстралингвистической реальности. В состав пропозиции входят актанты, способные к референции (субъект, объект, предикат).

Описание текста-оригинала (а также и каждого текста-ретранслята на третьем этапе исследования) осуществлялось при помощи денотативных карт, представляющих систему денотатных признаков текста, в состав которой входят три группы компонентов: 1) опорные элементы текста или смысловые вехи, подтемы, доминанты повествования; 2) элементы текста, подчиненные доминантам повествования и связанные с ними; 3) предикатные связи - предметные отношения между денотатами. Основным денотатам текста соответствуют подтемы и субподтемы, связанные между собой предметными отношениями: подтемы «замещают достаточно широкое содержание и выступают в качестве основного предмета соответствующего фрагмента», субподтемы «относятся к подтеме и образуют следующий уровень связей» (Новиков 1983: 137-138). На поверхностном уровне денотаты выражены именами, а отношения между ними - предикатными знаками.

Семантические роли в пропозициональных схемах обозначались при помощи следующих условных знаков: А (X) - Деятель, А - Актант, Ag - Агенс, Cir (temp) - Сирконстанта времени, Cir (loc) - Сирконстанта места, Obj Объект, G - Цель, S - Источник, Th - Тема, Dat - Датив, Ben - Бенефактив, Obl - Прочие, Rec - Реципиент, Act - Актор, N - Нейтрал; модификатор: Caus - Каузация; спецификатор: Neg - Отрицание; типы предикатов: $\mathrm{Ac}$ - Действие, Ex - Существование, $\mathrm{Ch}$ - Характеристика, Id - Идентификация и Классификация.

На втором этапе исследования аудиозаписи устных пересказов были транскрибированы по правилам устной разговорной речи, а затем с помощью выбранных методик анализа был зафиксирован состав пропозиций устных вторичных текстов.

На третьем этапе вторичные устные тексты, сопоставлялись с первичным текстом и определялась специфика устных интерпретаций содержания первичного письменного текста. При этом вслед за С.В. Гусаренко мы исходили из того, что «в ходе дискурсивной деятельности неизбежны семантические потери, которые являются следствием энтропийных процессов, сопутствующих функционированию актуального дискурса» (Гусаренко 2006: 101). Когнитивные действия, с одной стороны, «соотносят высказывание с внеязыковой реальностью, то есть представляют собой референциальные акты, с другой - формируют собственно лингвистический смысл высказывания, то есть являются пропозициональными актами» (Гусаренко 2006: 103). С учетом того, что «вторичный текст продуцируется в форме устного пересказа и обладает всеми характеристиками устной монологической речи (линейность и «одноразовость» презентации высказывания), а также данными об ограничениях на запоминание и обработку информации (processing constraints) человеческой памятью» (Дейк, Кинч 1988: 174), мы также полагаем, что в процессе усвоения дискурсивного образования неизбежно теряется его смысловая целостность, вплоть до почти полной утраты первоначальной структуры 
и содержания, и остается только то, что Т.А. ван Дейк назвал макроструктурами дискурса - теми смысловыми образованиями, которые остаются после прочтения текста или усвоения разговора и существенно отличаются от первоначальных форм и первоначального содержания (Дейк 1989) ${ }^{3}$.

\section{4. Денотативная карта исходного текста}

Единицей исследования вторичного устного текста является синтагма. Из всех речевых единиц она единственная функционирует в обеих формах речи - устной и письменной. При переходе устной (внутренней) речи в графическую синтагма, меняя свою материальную форму, сохраняет речепорождающую функцию. Фразы при этом трансформируются в предложения (Филатова 2019: 322). Синтагма как ситуативная единица индивидуального сознания реализуется в однословной и составной формах. Однословная синтагма коррелирует с основной единицей языка - словом, которое является строительным материалом предложения. Слово - константная единица общественного сознания; его значение задано для всех носителей языка и закреплено словарями (Филатова 2019: 319). При анализе первичного письменного текста на предмет его пропозициональных составляющих основной единицей выступает слово, способное реализоваться в предикатно-актантной структуре предложения.

Пропозиции текста-оригинала. Оригинал текста «О лидерстве» насчитывает 82 пропозиции, большая часть которых является логическими пропозициями, фиксирующими результат умственных операций; объем текста 252 слова.

В соответствии с принципом выделения ключевых слов, или «смысловых вех» (воспроизводство в тексте в функции ремы высказываний, связанность с другими подчиненными элементами текста), в терминологии А.И. Новикова (Новиков 1983), а также с правилами выведения макропропозиций (опущение, построение), приведенными Ван Дейком и У. Кинчем (Дейк, Кинч 1988: 153-211), мы зафиксировали макроструктуры первичного текста.

Текст может быть разделен на три смысловых блока со следующими макропропозициями: а) блок 1, 108 слов. «Изучение лидерства. Выделение двух фундаментальных лидерских ролей. Действия инструментального лидера. Действия экспрессивного лидера»; б) блок 2, 59 слов. «Выделение психологом Л.И. Уманским и его учениками новых типов лидеров»; в) блок 3, 85 слов. «Проиессы лидерства. Формальный лидер и неформальный лидер». Указанные смысловые вехи в нашем понимании представлены в каждом изученном тексте-ретрансляте.

Как уже указывалось, при сопоставлении денотативных карт текстаоригинала и текстов-ретранслятов выделялись смысловые вехи, элементы

${ }^{3}$ Возможно, макроструктуры на уровне языковой реализации смысла в максимально свернутом виде представляют собой некие ключевые слова или их набор. По этому поводу см. также (Грудева, Губушкина 2020). 
текста, подчиненные доминантам повествования, а также предикатные связи. Дополнительно указывался тип связей между элементами текста - референтный или референцированный. Референтный тип выявлен в случаях, если имеет место соотношение с конкретным референтом, а референцированный с референтной группой или через референтную среду. В последнем случае читателю необходимо провести ряд когнитивных и логических операций, позволяющих установить связи между кореферентными наименованиями.

Мы сравним более подробно первый блок текста-оригинала (35 пропозиций) с аналогичным блоком в каждом из 134 устных текстов-ретранслятов. Особенности денотативных карт вторичных текстов в первом, втором и третьем блоках текста-оригинала аналогичны и различаются исключительно семантическими классами предикатов.

Устные пересказы разделились на четыре группы по успешности передачи пропозициональных структур и в целом основной идеи текста-оригинала: группа 1 с наименьшим количеством пропозиций и ложным отображением денотативной карты текста; группа 2 с меньшим количеством пропозиций и слабым отображением денотативной карты текста; группа 3 с большим количеством пропозиций и адекватным отображением денотативной карты текста; группа 4 с адекватным или превышающим количеством пропозиций и успешным отображением денотативной карты текста.

Рассмотрим денотативную карту первого блока текста-оригинала.

Начальное предложение «Изучение лидерства ведется около ста лет» представляет собой две пропозиции «некто изучает что-то», «нечто длится какое-то время», где присутствует семантически предполагаемый, но лексически не обозначенный $\mathrm{A}(\mathrm{X})$ - деятель - актант (A) - агенс (Ag). Пропозиции синтаксически могут быть представлены следующим образом: $\mathrm{Ag}(\mathrm{X}) \operatorname{Pr}(\mathrm{X})$ A, A Pr Cir (temp). В тексте предложения фиксируются следующие элементы: денотаты первого порядка, предикация идеи, предикаты первого порядка; доминантная единица, лексема «лидерство», находящаяся в сильных позициях, в начале и в конце текста, и представляющая собой рему, может замещаться лексемой «лидер», сочетанием лексем «лидерские роли» и идентифицирует главный объект текста. По типу данное высказывание является референцированным.

Второе предложение - «В середине 50-х гг. ХХ в. были выделены две фундаментальные лидерские роли - роль инструментального (делового, целевого) лидера и роль лидера социально-эмоционального (экспрессивного)». Как видим, оно включает в себя пропозиции $\mathrm{Cir}$ Ag (X) Pr A «кто-то выделил что-то» и $\mathrm{A} \operatorname{Pr}(\mathrm{X}) \mathrm{A}$ conj А «что-то является/есть что-то» и объективирует именную структурную схему с конъюнкцией. Аналогично первому предложению фиксируются денотаты первого порядка, предикация идеи, предикаты первого порядка. При этом доминантные единицы, лексема «лидер» и сочетание «лидерские роли», находящиеся в сильных позициях, т.е. в начале и в конце текста, представляют собой рему; восходят к лексеме 
«лидерство», идентифицируют главный объект текста; тип высказывания референцированное. Как видим, глагол «выделен» употреблен в форме пассивного залога от глагола «выделять»; семантизируется как глагол, отображающий ситуацию поиска объекта ${ }^{4}$. Совмещенная семантическая модель для глагола «выделять» следующая. Типовая семантика: Живое существо ищет, находит в результате поиска что-л. скрытое, утерянное. Базовая модель: Субъект - предикат поиска - объект. Основные предикаты: искать, находить. Совмещенная семантическая модель: Модель «Субъект - предикат поиска и интеллектуальной деятельности - объект»: Человек обнаруживает что-л. в результате размышлений. $\mathrm{MCC}^{5}$ : N1Vf; Inf; Vpl 3 • ОРП: N4, где MCC минимальные структурные схемы; ОРП - основные, наиболее частотные расширители предиката. Предикаты: находить что-то, изобретать что-то, открывать что-то.

Третье предложение «Первая роль включает действия, направленные на организацию группы для достижения цели деятельности, решение поставленной перед группой задачи» пропозиционально представлено как А Pr (включает) A; A (X) Prs (действует); A (X) Prs (направляет) conj (организует) A; $\mathrm{A}(\mathrm{X}) \operatorname{Prs}$ (ставит цель = планирует что-то) conj (достигает) A (X) (субпропозиция); A (X) Prs (решает) A; A (X) Prs (поставил) А. Зафиксированы предикаты второго порядка, денотаты второго уровня; субподтемы подчинены подтеме, доминантам текста. В предложении имеют место референцированные связи, поскольку конкретный референт отсутствует, а предмет высказывания соотносится с более или менее широким кругом референтов, таких как «роль, группа».

Четвертое предложение «Инструментальный лидер - лидер, обладающий наибольшими знаниями и компетентностью, необходимыми для решения групповых задач и достижения целей» реализует следующие пропозициональные схемы: A Pr (0) A; A Prs (обладает) A; A Prs (знает) A; A Prs (решает) A; A Prs (достигает) A. Фиксируются денотаты первого порядка, предикация идеи, а также предикаты первого порядка. Доминантная единица - лексема «лидер» находится в сильных позициях, в начале и в конце текста, представляет собой рему и может замещаться сочетанием лексем «лидерские роли», идентифицирует главный объект текста. Тип высказывания определяем как референтное, поскольку текст указывает на конкретного референта - лидера. Для пропозиций, лежащих в основе предложений типа «Инструментальный лидер - лидер», типичны именные предикаты характеризующей семантики. Предикатам данного типа свойственна относительная независимость от времени: их «...потенциальная атемпоральность проявляется в способности к употреблению в общих суждениях» (Булыгина 1982: 14).

4 Экспериментальный синтаксический словарь / под ред. Л.Г. Бабенко. URL: https://www.slovari.ru/default.aspx?s=0\&p=2847 (дата обращения: 04.08.2020).

${ }^{5} \mathrm{~N} 1$ - сущ. в имен. пад., Vf - личная форма глагола, Inf - инфинитив, Vpl 3 - глагол в форме 3 л. множ. числа, N4 - сущ. в косв. пад. По этому поводу см. также (Lang, Schneider, Schwinn, Suchowolec \& Wöllstein 2020). 
Пятое предложение «Вторая роль представляет действия, относящиеся в основном к межличностным отношениям и регулирующие их» насчитывает следующие пропозиции: A (X) Prs (действует); A Pr (представляет) A; A Pr (относятся) A; A (X) Prs (относится) A (X); A Pr (регулируют) A. В пятом предложении фиксируются предикаты второго порядка, денотаты второго уровня (субподтемы, подчинены подтеме, доминантам текста). Тип высказывания - референцированное.

Шестое предложение «Экспрессивный лидер - лидер, влияющий на эмоциональную атмосферу группы, благодаря способности выражать интересы, мнения, настроения группы, уменьшать напряжение в ней»: $\mathrm{A} \operatorname{Pr}(0) \mathrm{A}$; A Pr (влияет) A; A Pr (имеет) A; A Pr (выражает) A; A Pr (уменьшает) A; A (X) Prs (напрягать) A (X). В данном предложении фиксируются денотаты первого порядка, предикация идеи, предикаты первого порядка. Доминантная единица - лексема «лидер», как и в четвертом предложении, находится в сильных позициях: в начале и в конце текста, представляет собой рему, объективируя таким образом референциальную связность текста, она может замещаться сочетанием лексем «лидерские роли»; тип высказывания - референтное.

В седьмом предложении «Его отличает способность откликаться на переживания других, понимать эти переживания, находить время для сочувствующей беседы» реализованы следующие пропозициональные схемы: A Pr (имеет) A; A Pr (откликается) A; A Prs (переживает); A Pr (понимает) A; A Pr (находит) A; A Prs (сочувствует) A (X); A Prs (беседует) A (X). Зафиксированы предикаты второго порядка, денотаты второго уровня (субподтемы), вступающие во множественные пересекающиеся связи с главным денотатом «лидер»; тип высказывания - референцированное.

Как видим, в пяти из семи предложений имеется референцированный тип высказываний и только в двух - референтный, что указывает на сложность текста и необходимость читателю осуществлять дополнительные когнитивные операции (о сложности текста см.: Hausendorf, Kesselheim, Kato \& Breitholz 2017, Kendeou, van den Broek, White \& Lynch 2007, McCarthy, McNamara, Solnyshkina, Tarasova \& Kupriyanov 2019, McNamara 2001, McNamara, Kintsch, Songer \& Kintsch 1996, McNamara \& Magliano 2009, Solovyev, Solnyshkina, Gafiyatova, McNamara \& Ivanov 2019, Solovyev, Solnyshkina \& Ivanov 2019).

\section{5. Пропозициональные структуры и референциальные характеристики неподготовленных устных пересказов}

Рассмотрим образцы четырех вышеуказанных текстов-ретранслятов: 1) пересказ респондента К $9004^{6}$ с наименьшим количеством пропозиций и

6 Подробно об осуществлении исследования и респондентах см. на сайте: https://shelly.kpfu.ru/e-ksu/docs/F2118867644/Otchet.RNF.2019_.18_18_00436.pdf?p_random= 543719 . 
ложным отображением денотативной карты текста; 2) пересказ респондента К9089 с меньшим количеством пропозиций и слабым отображением денотативной карты текста; 3) пересказ респондента К9074 с большим количеством пропозиций и адекватным отображением денотативной карты текста; 4) пересказ респондента К9126 с адекватным или превышающим количеством пропозиций и успешным отображением денотативной карты текста.

\section{1. Пересказ респондентов из группы с наименьшим количеством пропозиций и ложным отображением денотативной карты текста}

Начало пересказа: лидерство / подразумевает собой / (... $)^{7}$ два качества (...) // там (... 3 сек.) может быть экспрессивный лидер это / который / лидер / который переживает со своей / со своими (...) подчиненными // а те эмоциии / и инструментальный лидер / лидер / который обладает большим количеством знаний (...) // и (... 5 сек.) он (...). Конец пересказа первого блока текста-оригинала.

Первая фраза пересказа фиксирует попытки операции построения, применяемой для создания макропропозиций (Дейк, Кинч 1988), при которой несколько значимых замещаемых пропозиций двух начальных предложений первичного текста должны замениться на одну замещающую в пересказе на основании более общего значения последней. Здесь мы обнаруживаем явление другого порядка: модель «субъект - предикат поиска и интеллектуальной деятельности - объект: человек обнаруживает что-л. в результате размышлений» заменяется на модель «субъект - предикат воображения / предположения - объект: человек предполагает что-л., имеет догадки о чем-л.»; при этом реструктурируются не только предикаты, но и предикатные группы. Так, оба предиката (выделять $\rightarrow$ подразумевать) в актантно-предикатных структурах базовых моделей предполагают наличие субъекта, агенса - человека, а не абстрактного понятия «лидерство» (актанта), не способного к какомулибо виду деятельности, тем более ментального плана. Согласно «Русскому семантическому словарю» (Русский... 2007: 238) глагол «подразумевать» имеет значение «предполагать в мыслях кого-что-н., иметь в виду, не высказывая». «Экспериментальный синтаксический словарь» семантизирует глагол «предполагать» как глагол, входящий в класс предложений, отображающих ситуацию поиска объекта, а именно предложений, отображающих ситуацию воображения и предположения. Типовая семантика: Человек мысленно представляет что-л., воспринимает в мыслях, мечтах, фантазии, предполагая, догадываясь, воображая что-л. Базовая модель: Субъект - предикат воображения / предположения - объект. Основные предикаты: воображать, предполагать, представлять. Человек предполагает что-л., имеет догадки

${ }^{7}$ Многоточие в скобках (... 3 сек.) обозначает паузы, цифра - длительность пауз в секундах; / - конец синтагмы; // - окончание фразы. 
о чем-л. MCC: N1Vf; Inf; Vpl $3 \diamond$ OPП: N2; N4; (o) N6 ${ }^{8}$. Базовая модель глагола «подразумевать» по Framebank ${ }^{9}$ также: «Я подразумеваю под этим следующее: Snom V Sacc под + Sins».

В актантно-предикатной группе меняется также и объект предположения роль $\rightarrow$ качество. При этом гиперонимического сдвига, а также эквивалентной замены, интерпретации, сжатия (или компрессии) здесь не наблюдается. Фактически данная пропозиция является ложной, с утраченными, невысвеченными сирконстантами времени.

В ретрансляте фиксируется также операция построения, то есть замены нескольких значимых пропозиций источника на одну в пересказе на основании общего значения: способность откликаться на переживания других, понимать эти переживания $\rightarrow$ который переживает со своей / со своими (...) подчиненными.

Данный вариант пересказа для первого блока первичного текста насчитывает семь пропозиций, из которых две - неразвернутые, номинализированные, с элиминацией предикатно-актантной структуры и скрытой конъюнкцией: «а те эмощии /; и (... 5 сек.) он (...)». Согласно теории разговорной речи здесь наблюдаются также расчлененные парцеллированные конструкции «экспрессивный лидер это / который / лидер/», «лидер / лидер / который» с многочисленными незаполненными паузами, одно- и двусловными синтагмами, именительным темы и элементами автокоррекции «со своей / со своими».

\section{2. Пересказ из группы с меньшим количеством пропозиций и слабым отображением денотативной карты текста}

Приводим полный транскрипт всего текста-репродуктива, который отображает один блок текста-оригинала и попытки пересказа всего текста.

Начало пересказа: а (...) изучение (...) а лидерских отношений / ведется э уже несколько лет // а (...) в середине двадияатого века / выделили два э (... 3 сек.) / выделили два э (... 3 сек.) э две лидерских роли // э (...) первая это э (...) роль э (...) инструментального / а вторая э это роль со-социально э-эмоционального // пе э первая роль вк э (...8 сек.) пе (.. 8 сек.) пе а первый (...) счас первая роль (... 11 сек.) э ... (... 3 сек.) а первой э роль э изучают э (...) межличностные отношения / а во второй а э (... 5 сек.) сочиальноделовые // э (...). Конец всего пересказа.

В устном ретрансляте наблюдается изменение пациенса и модификаторов пропозиции, сирконстантов времени: а) по принципу гиперонимической замены и расширения значения понятия, не искажающее, впрочем, основное содержание: около ста лет $\rightarrow$ несколько лет; в середине 50-х г2. XX в. $\rightarrow$ $в$ середине двадизатого века; б) по принципу гипонимической замены

8 Экспериментальный синтаксический словарь.

9 FrameNets In Other Languages. URL: https://framenet.icsi.berkeley.edu/fndrupal/ framenets_in_other_languages (accessed 15 June 2020). 
пациенса: Изучение лидерства ведется около ста лет $\rightarrow$ изучение (...) а лидерских отношений / ведется э уже несколько лет. Следует заметить, что реципиент, безусловно, обладает определенными фоновыми знаниями по вопросу о лидерстве. Так, из психологии известно, что основой лидерства является специфический тип отношений управления, или лидерский тип. Лидерство отождествляется с наличием связанных с психикой человека отношений между лидером и его последователями. В этом случае можно признать, что замещаемая и замещающая пропозиции по предикатно-актантной структуре и семантическому наполнению практически идентичны.

В этом варианте пересказа фиксируются также две пропозиции со скрыто присутствующими актантами, именными предикатами характеризующей семантики, структурной схемой которых является « $\mathrm{Ni}$ соор $\mathrm{Ni}(\mathrm{X}) »$ при нулевой связке. Невысвеченный актант «лидер» легко реконструируется из предыдущего контекста: первая это э (...) роль э (...) инструментального / а вторая э это роль со-социиально э-эмоционального/. Вторая пропозициональная структура «выделили два э (... 3 сек.) / вылделили два э (... 3 сек.)» не является пропозицией, поскольку не изменяет фактического положения вещей, ощущается как десемантизированная хезитационная конструкция, свойственная разговорной речи. С одной стороны, это тавтологические конструкции «выделили два э (... 3 сек.) / вылелили два э (... 3 сек.) э», повторяющие предикат основной пропозиции «некто выделил что-то когда-то» с элементами автокоррекции «выделили два э (... 3 сек.) э две лидерских роли/». С другой стороны, тавтологический повтор позволяет нам реконструировать когнитивный поиск семантической связи в пропозициональной структуре с невыраженным агенсом Cir $\mathrm{A}(\mathrm{X}) \operatorname{Pr} \mathrm{A}$. C точки зрения разговорной речи это также расчлененная структура.

Другие элементы пересказа: а) ne (...8 сек.) - вокально-консонантный комплекс представляет собой начальные сочетания звуков; с точки зрения закономерностей построения цепи сигналов является информативным звукокомплексом, в котором каждая последующая единица предсказывается предыдущими и, таким образом, может быть легко реконструирована (ne = первая роль; вк = включает). Можно предположить линейный поиск и извлечение из памяти элементов пропозициональной структуры (субъектов, объектов и их связей), попытку их семантизации и вербализации; б) счас элемент мнемического переживания, своего рода слово-паразит, асемантическая единица речи, не несущая информационной нагрузки и не выполняющая дополнительных функций, имеющих отношение к информационному содержанию речи. Характерные черты этих слов или сочетаний - избыточность, немотивированность, несовпадение со словарным значением, повышенная частотность в тексте, интонационное выделение, неучастие в предложении, сочетание с паузами, вызванными затруднением в речи.

Данный вариант пересказа насчитывает девять пропозиций, из которых одна - со скрытым предикатом, одна пропозиция не развернута со скрытыми актантами и предикатом. 
Консонантно-вокальный комплекс «вк $(\mathrm{CC}), n e(\mathrm{CV}), n e(\mathrm{CV})^{10} »$ представляет собой поиск слов, элемент извлечения из памяти конструктов и структур высказывания, поиск связей семантических сетей: «что-то включает что-то, образует элемент его структуры». Когнитивный поиск связей манифестируется через многочисленные паузы и усеченные структуры лексических единиц высказывания, лексико-семантическая реконструкция которых позволяет гопотетически выстроить следующую синтаксему, не озвученную во внешней речи: «Первая роль включает». Иными словами, фонологические сочетания $\mathrm{CC}, \mathrm{CV}$ «семантизируют» и предвосхищают появление конкретной лексико-семантической группы. Можно предположить, что консонантновокальные комплексы «вк, ne, ne» фиксируют моторно (моторикой, артикуляцией, артикуляторно) работу внутренней речи. Пропозиция без агенса - деятеля заменяется на пропозицию «некто изучает что-то», и данная пропозиция оформляется элементами синтаксического синтаксиса во внешней речи.

Сравнивая два пересказа, мы констатируем, что в варианте пересказа из группы с меньшим количеством пропозиций и слабым отображением денотативной карты текста реципиент логически верно осуществляет референцию соотнесение референта с предметным (абстрактным) миром. Это позволяет ему сначала выделить типы лидеров, а потом их роли и функции, поскольку последние не могут выполнять действия, так как не являются деятелями. Таким образом, выделенные выше пропозиции для первого блока текстаоригинала заменяются в тексте-ретрансляте событийными пропозициями с обозначенными деятелями (А) и предикатами действия (Pr), выраженными глаголами активного, а не страдательного залога и передающими глубинную структуру $\mathrm{SPO}^{11}$, усвоенную в процессе речевого онтогенеза.

Семантические и референциальные сложности первичного текста, скрытость референта обусловили неверную референцию, трудности в нахождении и ретрансляции референта во вторичном тексте из группы с наименьшим количеством пропозиций и ложным отображением денотативной карты текста. Попытка заменить референт «лидер» на референт «роли» привела к невозможности выстраивания семантической сети в семантической памяти реципиента и созданию ложных семантических связей, не соответствующих заложенным в первичном тексте. Так, первая роль не связана с межличностными отношениями, а вторая - с социально-деловыми, кроме того, в первичном тексте отсутствует само понятие социально-деловых отношений ( а первой э роль э изучают э (...) межличностные отношения / а во второй а э (... 5 сек.) сочиально-деловые//).

10 « $»$ обозначает согласные фонемы (от англ. consonant), «V» обозначает гласные фонемы (от англ. vowel).

${ }^{11} \mathrm{SPO}$ - Subject, Predicate, Object, модель типа предложения с порядком слов «подлежащее, сказуемое, дополнение». 


\section{3. Пересказ из группы с большим количеством пропозиций и адекватным отображением денотативной карты текста}

Начало пересказа: изучение феномена лидерство ведется около ста лет // в пятидесятых годах двадиатого века / а было выделено а (...) два типа э лидерских ролей // первая / это (...) а (...) лидер инструментальный / и второе / это лидер экспрессивный // первая роль заключается в том / что (...) а (...) лидер обладает наибольшими знаниями / и значса ${ }^{12}$ организащией (...) э сочиальной группь // а (...) вторая роль лидера / (...) экспрессивная а (...) / заключается в э (...) / с так сказать / в моральной поддержке участников групnы // a. Конец пересказа одного блока текста-оригинала.

Пересказ насчитывает 11 пропозиций. В нем осуществлены операции трансформации исходных замещаемых пропозиций и опущения отдельных элементов актантно-предикатного узла; то, что было выражено в первичном тексте 12 пропозициями, сократилось во вторичном тексте до 3: «первая роль заключается в том / что (...) а (...) лидер обладает наибольшими знаниями / и знаиса организацией (...) э соииальной группыл», где «роль имеет своей сутью то, что», «лидер знает» и «лидер организует». Аналогичное наблюдается при описании действий экспрессивного лидера: 16 пропозиций трансформировались в 5. Пересказ производит впечатление определенной макроструктуры, полученной в результате операций сворачивания исходных пропозиций, и представляет собой краткую форму пересказа текста с высвечиванием определенных смысловых вех, таких как «Изучение лидерства. Выделение двух фундаментальных лидерских ролей. Действия инструментального лидера. Действия экспрессивного лидера». С точки зрения пропозициональной структуры вторичный текст обнаруживает следующее: 1) расширение пропозициональной структуры за счет актантов с абстрактным значением, восходящим к гиперонимическим отношениям, добавление актантов: изучение лидерства $\rightarrow$ изучение феномена лидерство; 2) расширение пропозициональной структуры с включением модификаторов актантов для пациенса: были выделень две фундаментальные лидерские роли $\rightarrow$ было выделено а (...) два типа э лидерских ролей; 3) пропозиция с невыраженным абстрактным субъектом «заключается в э (...) / с так сказать / в моральной поддержке участников группь»» контекстно связывается с доминантной группой «вторая роль лидера $\rightarrow$ лидер» и имеет усеченную структуру (X) +V в + Sloc; 4) попытка замены субъекта-агенса на абстрактный субъект-тему «первая роль включает

12 Согласно правилам транскрибирования записей устной речи GAT 2 (URL: http://www.gespraechsforschung-ozs.de/heft2009/px-gat2.pdf, accessed 4 August 2020), принятым нами в качестве основы для создания транскриптов записей устных пересказов школьников и не имеющим аналогов в практике исследования устных записей русской разговорной речи, словоупотребление «знацса», как и его сочетание «знацса организацией», не является грамматической или стилистической ошибкой, но является единицей документа, в данном случае транскрипта, не подлежащего дальнейшему корректированию. Транскрипт призван фиксировать дословно и точно то, что озвучено в устной речи. 
действия $\rightarrow$ первая роль заключается в том». Так, согласно словарю, значение глагола «включать» трактуется как «поместить, ввести, внести в состав, в число кого-чего-н.» (Русский... 2007: 217) и по Framebank имеет предикатную структуру Snom $\rightarrow$ агенс $\rightarrow$ Субъект $\rightarrow$ лицо $\rightarrow$ включать, включить $\rightarrow$ Предикат $\rightarrow$ Sасс $\rightarrow$ пациенс $\rightarrow$ Объект $\rightarrow$ в + Sасс $\rightarrow$ конечная точка множество $\rightarrow$ Периферия. Значение глагола «заключаться» - «состоять в чем-н., иметь своей сутью что-н.» (Русский... 2007: 90) и по Framebank имеет предикатную структуру Snom $V$ в + S loc: Snom $\rightarrow$ темa $\rightarrow$ Cубъекm $\rightarrow$ абстрактный $\rightarrow$ заключаться $\rightarrow$ Предикат $\rightarrow$ в + Sloc $\rightarrow$ место $\rightarrow$ Периферия $\rightarrow$ текст. В пересказе фиксируется также постпозитивное расположение определительного прилагательного, иначе - конструкция, типичная для устной формы коммуникации: в нашем случае - постпозитивное определение ремы: это (...) а (...) лидер инструментальный / и второе / это лидер экспрессивный; вторая роль лидера / (...) экспрессивная а. Иными словами, мы наблюдаем в пересказе качества актуализированного синтаксического строя или синтаксиса актуализированного - с расчлененным грамматическим составом предложения, с выдвижением семантически значимых компонентов предложения в актуальные позиции, с нарушением синтагматических цепочек.

\section{4. Пересказ из группы с адекватным} или превышающим количеством пропозиций и успешным отображением денотативной карты текста

Начало пересказа: э с существует / э э выделяют / ученые выделяют разные э виды лидерства // э вид лидерства / э уже изучается около ста лет // э изначально выделяли таких лидеров как / э (...) фор э (...) как э и эм эмочиональные / то есть экспрессивные / и э инструментальные // инструментальный лидер / это тот лидер / который наставляет группу на нужный путь // указывает свои э (...) / какие э решения делать принимать / помогать и достижению целей/ и (...) других потребностей группь // (...) именно а это / (...) э именная группа э лидера / (...) экспрессивный лидера обл э ой / именно инструментальный лидер / обладает такими качествами как очень сна трудоспособный / и очень э у (...) целеустремленный // они их долг / они считают своим долгом то / чтобы э поставить людей на нужный путь // э экспрессивные лидеры являются лидерами / которые э (...) э в эмоциональном и психологическом плане помогают какой-то группе // они найдут всегда время на какую-то беседу / который нужно / если кому-то надо помочь // они всегда а эмоциионально поддерживают лю э группу // э э могут с ними поговорить / э решить их проблемы и так далее //Конец пересказа одного блока текста-оригинала. Пересказ насчитывает 35 пропозиций.

В данном пересказе осуществлены следующие операции: 1) попытка конкретизировать исходную пропозицию первичного текста путем введения новой пропозиции, нового положения дел, не имеющего места быть в исходном 
тексте: обладает такими качествами как очень сна трудоспособный / и очень э у (...) изелеустремленный//; они их долг / они считают своим долгом то / чтобы э поставить людей на нужный путь/; э в эмоциональном и психологическом плане; помогают какой-то группе; 2) попытка не только передачи информации, но и ее интерпретации и конкретизации, в 65\% случаев за счет добавления во вторичном тексте актантно-предикатных узлов, отображающих на семантическом уровне несуществующее положение дел: могут с ними поговорить / э решить их проблемы, если кому-то надо помочь; который наставляет группу на нужный путь; и (...) других потребностей группьы.

Одним из наиболее распространенных явлений, характеризующих все пересказы, является свободное оперирование сирконстантами пропозиций: они могут выражаться точно, неточно с употреблением слова «около» либо утрачиваться. Так, например, сирконстант времени «B середине $50-x$ г2. $X X$ в.» в данном пересказе был утрачен полностью. Вполне вероятно, что данная информация с точки зрения реципиента не относилась к важным смысловым вехам текста.

Жанр первичного текста влияет на тип устного пересказа таким образом, что в пересказах учебных текстов в 90\% случаев осуществляется: 1) замена логических пропозиций на событийные, передающие глубинную структуру SPO, усвоенную в процессе речевого онтогенеза; 2) замена актантов с абстрактным значением на субъекты-агенсы - деятелей, активно выполняющих какие-либо действия.

\section{6. Обсуждение результатов}

Описание процедуры появления тех или иных единиц вторичного текста является одним из важных моментов в изучении специфики текстов-репродуктивов. В результате реструктуризации пропозициональных структур первичные (письменные) и вторичные (устные) неподготовленные тексты обнаруживают следующее.

1. Частичная реструктуризация пропозиций первичного текста (замещаемые пропозиции) в устном пересказе не нарушает единство его внутреннего (содержательного, смыслового) и внешнего (формально-языкового) плана, определяющего его цельность и связность и являющегося сигналами семантического и смыслового целого. «Денотативная карта» текста, денотативная структура текста, иерархия систем предикатов (предикаты первого порядка (предикация идеи) - макроструктура и макропропозиция), предикаты второго порядка (предикации основного содержания, микропропозиции), представляющие собой замещающие пропозиции) остаются сохраненными. В некоторых случаях наблюдается удержание предикатов третьего и четвертого порядков (предикации полноты содержания). Количество пропозиций сохраняется (16\% текстов-ретранслятов), сокращается (75\% текстов-ретранслятов) либо увеличивается (9\% текстов-ретранслятов). Наблюдаются следующие варианты: трансформация пропозиции образа в несколько субпропозиций, 
являющихся результатом ее семантически правильного расчленения; перемещение актантов из субпропозиций в главные пропозиции; введение новых пропозиций, обозначающих новое положение дел и свидетельствующих об этапах интерпретации (вторичная, третичная интерпретация).

2. Полная реструктуризация пропозиций первичного текста в устном пересказе нарушает единство его внутреннего (содержательного, смыслового) и внешнего (формально-языкового) планов, определяющих его цельность и связность. «Денотативная карта» текста, иерархия систем предикатов (предикаты первого порядка (предикация идеи) - макроструктура и макропропозиция), предикаты второго порядка (предикации основного содержания)) не сохраняются, частично трансформируются либо утрачиваются. При реактуализации макропропозиции утрачиваются значимые структурные компоненты пропозиции, коммуникативно важные компоненты ремы и вся пропозиция. Предикаты третьего и четвертого порядков (предикации полноты содержания) не фиксируются. Количество пропозиций значительно сокращается. Наблюдается феномен сложного, или многоаспектного, когнитивного диссонанса, реализующегося в комплексе на различных уровнях языковой личности: вербально-семантическом, когнитивном и мотивационно-прагматическом.

3. Таким образом, исходя из анализа материала, мы предлагаем следующую последовательность изучения этапов и закономерностей смыслового восприятия письменного текста и его устного воспроизводства, неподготовленного пересказа, с включением отдельных составляющих процессов восприятия и продукции: (Начало эксперимента / Определение задания) $\rightarrow$ Первичное визуальное: тактильное восприятие $\rightarrow$ Первичная интерпретация (текст как письменная фиксация определенной информации на определенном носителе информации) $\rightarrow$ Чтение / Вторичное визуальное восприятие: индивидуальная техника чтения $\rightarrow$ Кодирование в памяти (кратковременная память, эпизодическая память): вторичная интерпретация: семантизирующее понимание: когнитивное понимание (референция, денотация, пропозицияпредикация, выделение тема-рематических блоков, макропропозицияноминализация) $\rightarrow$ Рефлексия: Первичное искажение $\rightarrow$ Свертывание: текст как смысловой сгусток: инвариант $\rightarrow$ Подготовка к устному изложению: извлечение из памяти: развертывание: пересказ $\rightarrow$ Распредмечивающее понимание: реактуализация предикации (макропропозиция-номинализация, реконструкция пропозиций, реконструкция актантов, конструкция субпропозиций, реконструкция тема-рематических блоков) $\rightarrow$ Третичная интерпретация: осмысление $\rightarrow$ Рефлексия: прагматическое осмысление: вторичное искажение $\rightarrow$ устная реализация (автокоррекция, перебивы, тавтологические повторы, усечения словоформ в виде начальных вокально-консонантных комплексов, парцеллированные структуры, именительный темы, аструктурированность, паузы хезитации, десемантизированные хезитационные конструкции, убыстрение или замедление темпа речи) $\rightarrow$ текст как вариант. 
Предложенные характеристики «текста-варианта» являются одновременно его неотъемлемыми составляющими, облегчающими школьнику ментальный поиск слов и извлечение их из памяти, создание пропозиционального каркаса, построение тема-рематических блоков и пересказа в целом.

Первичный текст, подвергшийся многочисленным этапам интерпретации и рефлексии, не является содержательно полностью идентичным и прагматически равным вторичному устному тексту, несмотря на то что первичный текст сохраняет свою мотивирующую роль в деривационной структуре вторичного текста. Вторичный текст в таком понимании есть продолжение, развитие, функция исходного текста.

Следует уточнить, что ментальная работа некоторых этапов происходит одновременно и скрыта от исследователя, и лишь теоретические данные и анализ вторичных текстов позволяют реконструировать механизм создания текстов-репродуктивов.

\section{7. Заключение}

Оценивать вторичные тексты можно с точки зрения успешности или неуспешности трансфера информации первичного текста; это было бы более справедливым, если бы мы характеризовали вторичный письменный текст, продуманный, многократно логически и грамматически скорректированный в процессе написания. Неподготовленный устный вторичный текст отображает одновременное линейное взаимодействие памяти, языка и моторики при произношении высказывания вслух и, скорее, характеризует способность личности осуществлять связанные устные пересказы.

Анализ семантики единиц вторичного текста, а также их пропозициональных структур показывает, что любая значимая единица вторичного текста мотивирована не только единицами предтекста ${ }^{13}$, но и первичным текстом. Степень мотивированности зависит от действия механизмов замены на семантическом уровне: эквивалентная замена, интерпретация, сжатие, компрессия; их успешность - от фоновых знаний реципиента, его эмоционального настроя, психологических характеристик личности (уровень тревожности), умения и навыков пересказа.

(C) Anna A. Petrova and Marina I. Solnyshkina, 2021
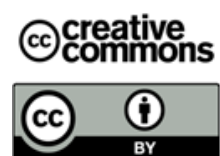

This work is licensed under a Creative Commons Attribution 4.0 International License https://creativecommons.org/licenses/by/4.0/

${ }^{13}$ Предтекстом в данной модели обозначается стадия формирования установки на чтение текста, которая включает, согласно модели, этапы определения задания, первичного визуального: тактильного восприятия, первичной интерпретации. 


\section{Финансирование}

Эксперимент по пониманию текста и его анализу финансировался грантом Российского научного фонда № 18-18-00436 «Сложность текстов на русском языке». Проектирование и разработка «денотативных карт» выполнены за счет средств Программы стратегического академического лидерства Казанского (Приволжского) федерального университета.

Участие авторов: Солнышкина М.И. - концепция и дизайн исследования; Петрова А.А. - сбор и обработка материалов, анализ полученных данных.

\section{СПИСОК ЛИТЕРАТУРЫ / REFERENCES}

Арутюнова Н.Д. Лингвистические проблемы референции // Новое в зарубежной лингвистике. Вып. 13. М.: Прогресс, 1982. С. 5-40. [Arutjunova, Nina D. 1982. Lingvisticheskie problemy referencii (Linguistic problems of reference). In New in Foreign Linguistics. Vol. 13. 5-40. Moscow: Progress. (In Russ.)].

Арутюнова Н.Д. Понятие пресуппозиции в лингвистике // Известия АН СССР. Серия литературы и языка. 1973. Т. XXXII. Вып. I. C. 85-95. [Arutjunova, Nina D. 1973. Ponjatie presuppozicii $\mathrm{v}$ lingvistike (The concept of presupposition in Linguistics). Bulletin of the USSR Academy of Sciences. Literature and Language Series XXXII (I). 85-95. (In Russ.)].

Бабенко Л.Г., Казарин Ю.В. Лингвистический анализ художественного текста. Теория и практика: учебник, практикум. М.: Флинта; Наука, 2005. 496 с. [Babenko, Lyudmila G. \& Kazarin, Yurii V. 2005. Lingvisticheskij analiz hudozhestvennogo teksta. Teorija i praktika: uchebnik, praktikum (Linguistic analysis of literary text. Theory and practice: textbook, workshop). 496. Moscow: Flinta; Nauka. (In Russ.)].

Богин Г.И. Обретение способности понимать: Введение в филологическую герменевтику. Тверь, 2001. 731 с. [Bogin, Georgii I. 2001. Obretenie sposobnosti ponimat': Vvedenie $v$ filologicheskuju germenevtiku (Gaining the Ability to Understand: An Introduction to Philological Hermeneutics). 731. Tver'. (In Russ.)].

Боголюбов Л.Н. Обществознание. 10 класс: учебник для общеобразоват. учреждений: базовый уровень. 5-е изд. М.: Просвещение, 2009. 351 с. [Bogoljubov, Leonid N. 2009. Obshheetvoznanie. 10 klass: ucheb dlja obshheobrazovat. uchrezhdenij: bazovyj uroven' (Social Studies. Grade 10: textbook for general education. institutions: basic level). 5th edn. 351. Moscow: Prosveshhenie. (In Russ.)].

Булыгина Т.В. К построению типологии предикатов в русском языке // Семантические типы предикатов / АН СССР, Ин-т языкознания. М.: Наука, 1982. С. 7-86. [Bulygina, Tat'yana V. 1982. K postroeniju tipologii predikatov v russkom jazyke (Towards the construction of a typology of predicates in Russian). In Semanticheskie tipy predikatov. 7-86. Moscow: Nauka. (In Russ.)].

Ван Дейк Т.А., Кинч В. Стратегии понимания связного текста // Новое в зарубежной лингвистике. Вып. XXIII: Когнитивные аспекты языка. М.: Прогресс, 1988. C. 153-211. [van Dijk, Teun A. \& Kintsch, Val'ter. 1988. Strategii ponimanija svjaznogo teksta (Strategies for understanding coherent text). In New in Foreign Linguistics. Vol. XXIII: Cognitive aspects of language. 153-211. Moscow: Progress. (In Russ.)].

Ван Дейк Т.А. Язык. Познание. Коммуникация / пер. с англ. М.: Прогресс, 1989. 312 с. [van Dijk, Teun A. 1989. Language. Cognition. Communication. 312. Moscow: Progress. (In Russ.)]. 
Выготский Л.С. Собрание сочинений: в 6 т. Т.2. Проблемы общей психологии / под ред. В.В. Давыдова. М.: Педагогика, 1982. 504 с. [Vygotskij, Lev S. 1982. Sobranie sochinenij: v 6 t. T. 2. Problemy obshhej psihologii (Collected works: In 6 volumes. Vol. 2. Problems of General Psychology). V.V. Davydov (ed.). 504. Moscow: Pedagogika. (In Russ.)].

Голев Н.Д. Динамический аспект лексической мотивации. Томск: Изд-во Томского унта, 1989. 252 c. [Golev, Nikolai D. 1989. Dinamicheskij aspekt leksicheskoj motivacii (The dynamic aspect of lexical motivation). 252. Tomsk: Tomskii un-t Publ. (In Russ.)].

Грудева Е.В., Губушкина А.А. Набор ключевых слов и устный пересказ как вторичные тексты (на материале вторичной речевой деятельности учащихся 6-х классов) // Вестник Череповецкого государственного университета. 2020. № 2 (95). С. 56-72. [Grudeva Elena V. \& Gubushkina Anna A. 2020. Set of keywords and oral retelling as secondary texts (by the material of the 6th grade students' secondary speech activities). Cherepovets State University Bulletin 2 (95). 56-72. (In Russ.)]. DOI: 10.23859/19940637-2020-2-95-5.

Гусаренко С.В. Прагматика релевантности в современном русском нарративе (на материале художественных и учебно-научных текстов) // Гуманитарные и юридические исследования. СКФУ. 2016. № 4. С. 220-226. [Gusarenko, Sergei V. 2016. Pragmatics of relevance in modern Russian narrative (on literary and educational scientific texts). Humanities and Law Studies. NCFU 4. 220-226. (In Russ.)].

Гусаренко С.В. Прагматика релевантности в современном русском тексте-описании (на материале художественных и учебно-научных текстов) // Гуманитарные и юридические исследования. СКФУ. 2017. № 4. С. 179-182. [Gusarenko, Sergei V. 2017. Pragmatics of relevance in modern Russian text-description (derived from literary and educational scientific texts). Humanities and Law Studies. NCFU 4. 179-182. (In Russ.)].

Гусаренко С.В. Пропозиция как компонент актуального дискурса // Гуманитарные и юридические исследования. СКФУ. 2015. № 4. С. 159-164. [Gusarenko, Sergei V. 2015. Proposition as a component of actual discourse. Humanities and Law Studies. NCFU 4. 159-164. (In Russ.)].

Гусаренко С.В. Семантические потери в актуальном дискурсе как следствие энтропийных процессов // Вестник Ставропольского государственного университета. 2006. № 45. C. 101-110. [Gusarenko, Sergei V. 2006. Semantic losses in actual discourse as the consequence of entropy processes. Vestnik Stavropol'skogo gosudarstvennogo universiteta 45. 101-110. (In Russ.)].

Дридзе Т.М. От герменевтики к семиосоциопсихологии: от «творческого» толкования текста к пониманию коммуникативной интенции автора // Социальная коммуникация и социальное управление в экоантропоцентрической и семиосоциопсихологической парадигмах: в 2 кн. Кн. 2. М.: Изд-во Ин-та социологии РАН, 2000. C. 115-137. [Dridze, Tamara M. 2000. Ot germenevtiki k semiosociopsihologii: ot «tvorcheskogo» tolkovanija teksta k ponimaniju kommunikativnoj intencii avtora (From Hermeneutics to Semiosociopsychology: from the "creative" interpretation of the text to understanding the communicative intention of the author). In Social Communication and social management in the ecoanthropocentric and semiosociopsychological paradigms: in 2 Vols. Vol.2. 115-137. Moscow: In-t sociologii RAN Publ. (In Russ.)].

Еременко В.И. Воспоминание и знание как формы переживания прошлого: автореф. дис. ... канд. псих. наук: 19.00.01. М., 2007. 26 с. [Eremenko, Viktoriya I. 2007. Vospominanie i znanie kak formy perezhivanija proshlogo (Recollection and knowledge as forms of experiencing the past): avtoref. dis. ... kand. psih. nauk: 19.00.01. 26. Moscow. (In Russ.)]. 
Жинкин Н.И. Речь как проводник информации. М.: Наука. 1982. 160 с. [Zhinkin, Nikolai I. 1982. Rech' kak provodnik informacii (Speech as a conductor of information). 160. Moscow: Nauka. (In Russ.)].

Земская Е.А. Русская разговорная речь: лингвистический анализ и проблемы обучения: учеб. пособие. М.: Флинта; Наука, 2004. 239 с. [Zemskaja, Elena A. 2004. Russkaja razgovornaja rech': lingvisticheskii analiz $i$ problemy obuchenija: ucheb. posobie (Russian colloquial speech: Linguistic analysis and learning problems). 239. Moscow: Flinta; Nauka. (In Russ.)].

Зимняя И.А. Лингвопсихология речевой деятельности. М.: Московский психолого-социальный институт; Воронеж: НПО «МОДЭК», 2001. 432 с. [Zimnjaja, Irina A. 2001. Lingvopsihologija rechevoj dejatel'nosti (Linguopsychology of speech activity). 432. Moscow: Moskovskij psihologo-social'nyj institute Publ.; Voronezh: NPO «MODJeK». (In Russ.)].

Исенбаева Г.И. Методология порождения вторичного текста: когнитивный аспект. Орск: Издательство ОГТИ, 2009. 191 с. [Isenbaeva, Galina I. 2009. Metodologija porozhdenija vtorichnogo teksta: kognitivnyj aspect (Secondary Text Generation Methodology: Cognitive Aspect). 191. Orsk: OGTI Publ. (In Russ.)].

Кашкин Е.В., Ляшевская О.Н. Семантические роли и сеть конструкций в системе FrameBank // Компьютерная лингвистика и интеллектуальные технологии. Материалы ежегодной Международной конференции «Диалог»: в 2 т. Т. 1, Вып. 12 (19). M., 2013. C. 325-344. [Kashkin Egor V. \& Lyashevskaya Ol'ga N. 2013. Semantic roles and construction net in russian FrameBank. In Computational Linguistics and Intellectual Technologies. Papers from the Annual International Conference "Dialogue" 1 (12). 325-344. (In Russ.)].

Клюев Е.В. Речевая коммуникация: учебное пособие для университетов и институтов. М.: РИПОЛ КЛАССИК, 2002. 320 с. [Kljuev, Evgenii V. 2002. Rechevaja kommunikacija: Uchebnoe posobie dlja universitetov $\mathrm{i}$ institutov (Speech communication). 320. Moscow: RIPOL KLASSIK. (In Russ.)].

Куканова В.В. О характере мотивированности неподготовленного текста-пересказа // Вестник Санкт-Петербургского университета. Сер. 9. 2008. Вып. 3. Ч. II. С. 73-81. [Kukanova, Viktoriya V. 2008. O haraktere motivirovannosti nepodgotovlennogo tekstapereskaza (On the nature of the motivation of an unprepared recall). Vestnik of Saint Petersburg University. Series 9, 3, II. 73-81. (In Russ.)].

Леонтьев А.А. Основы психолингвистики. М.: Academia, 2005. 287 с. [Leont'ev, Aleksei A. 2005. Osnovy psiholingvistiki (Fundamentals of Psycholinguistics). Moscow: Academia. (In Russ.)].

Леонтьев Д.А. Психология смысла: природа, строение и динамика смысловой реальности. М.: Смысл, 2007. 511 с. [Leont'ev, Dmitrii A. 2007. Psihologija smysla: priroda, stroenie i dinamika smyslovoj real'nosti (The psychology of meaning: nature, structure and dynamics of meaningful reality). 511. Moscow: Smysl. (In Russ.)].

Мустайоки А. Теория функционального синтаксиса: от семантических структур к языковым средствам. М.: Языки славянской культуры, 2006. 512 с. [Mustajoki, Arto. 2006. Teorija funkcional'nogo sintaksisa: ot semanticheskih struktur $k$ jazykovym sredstvam (Functional syntax theory: from semantic structures to linguistic means). 512. Moscow: Jazyki slavjanskoj kul'tury. (In Russ.)].

Новиков А.И. Семантика текста и ее формализация. М.: Наука, 1983. 216 с. [Novikov, Anatolii I. 1983. Semantika teksta $i$ ejo formalizacija (Semantics of the text and its formalization). 216. Moscow: Nauka. (In Russ.)]. 
Падучева Е.В. Высказывание и его соотнесенность с действительностью: Референциальные аспекты семантики местоимений. 6-е изд. М.: ЛКИ, 2010. 296 с. [Paducheva, Elena V. 2010. Vyskazyvanie $i$ ego sootnesennost' s dejstvitel'nost'ju: Referencial'nye aspekty semantiki mestoimenij (Utterance and its relationship with reality: Referential aspects of pronoun semantics). 6th edn. 296. Moscow: LKI. (In Russ.)].

Петрова А.А., Солнышкина М.И. Письменная коммуникация: текстовый и лингвистический подходы к теории и эмпирии // Вестник Волгоградского государственного университета. Серия 2, Языкознание. 2019. Т. 18. № 3. С. 276-281. [Petrova Anna A., Solnyshkina Marina I. 2019. Pis'mennaja kommunikacija: tekstovyj i lingvisticheskij podhody k teorii i jempirii (Writing communication: textual and linguistic approaches to theory and empirism). Science Journal of Volgograd State University. Linguistics 18 (3), 276-281. (In Russ.)]. DOI: https://doi.org/10.15688/jvolsu2.2019.3.23.

Сахарный Л.В. Введение в психолингвистику. Курс лекций. Л.: Изд-во Ленингр. ун-та, 1989. 184 c. [Saharnyj, Leonid V. 1989. Vvedenie v psiholingvistiku. Kurs lekcij (Introduction to Psycholinguistics. Lecture course). Leningrad: Leningr. Un-t Publ. (In Russ.)].

Филатова Е.В. Русская речь и ее реальные исходные единицы // Russian Language Studies. Русистика. 2019. Vol. 17, No. 3. P. 315-325. [Filatova, Elena V. 2019. Russian speech and its real initial units. Russian Language Studies 17 (3), 315-325. (In Russ.)]. DOI: 10.22363/2618-8163-2019-17-3-315-325.

Шелестюк Е.В. Этапы и закономерности смыслового восприятия текста // Вопросы когнитивной лингвистики. 2010. № 2 (023). С. 85-90. [Shelestiuk, Elena. V. 2010. Laws and stages of text comprehension). Voprosy Kognitivnoy Lingvistiki 2 (023), 85-90. (In Russ.)].

Шмелева Т.В. Предложение и ситуация в синтаксической концепции Т.П. Ломтева // Филологические науки. 1983. № 3. С. 42-48. [Shmeleva, Tat'yana V. 1983. Predlozhenie i situacija $v$ sintaksicheskoj koncepcii T.P. Lomteva (Sentence and Situation in the syntactic concept of T.P. Lomtev. Philological Science 3, 42-48. (In Russ.)].

Chomsky, Noam. 1969. Aspects of the Theory of Syntax. M.I.T. Press.

Chomsky, Noam. 1986. Knowledge of Language: its Nature, Origin, and Use. New York: Praeger.

Elosúa, M. Rosa, Juan Antonio García-Madruga, José Vila, Isabel Gómez-Veiga \& Laura Gil. 2013. Improving reading comprehension: From metacognitive intervention on strategies to the intervention on working memory executive processes. Universitas Psychologica. 12(5). 1425-1438. DOI: 10.11144/Javeriana.UPSY12-5.ircm.

Fillmore, Charles J. 1968. The Case for Case. In Bach E. \& Harms (eds.) Universals in Linguistic Theory. New York. 1-88.

Fillmore, Charles J. 1977. The Case for Case Reopened. In Cole P. \& J.M. Sadock (eds.) Grammatical Relations. New York: Acad. Press. 59-81.

Fillmore, Charles J. 1982. Frame semantics, Linguistics. The morning calm: Selected papers from the SICOL-1981. Seoul: Hanship. 111-137.

Friederici, Angela D. 1995. The time course of syntactic activation during language processing: A model based on neuropsychological and neurophysiological data. Brain and Language, 50 (3), 259-281. DOI: https://doi.org/10.1006/brln.1995.1048.

Gesprächsanalytisches Transkriptionssystem 2 (GAT 2). Gesprächsforschung - OnlineZeitschrift zur verbalen Interaktion. (2009, Ausgabe 10, Seite 353-402). Retrieved from http://www.gespraechsforschung-ozs.de/heft2009/px-gat2.pdf

Hausendorf, Heiko, Wolfgang Kesselheim, Kato Hiloko \& Martina Breitholz. 2017. Textkommunikation. Ein textlinguistischer Neuansatz zur Theorieund Empirie der Kommunikation mit und durch Schrift. Berlin; Boston: De Gruyter. (In German). 
Kendeou, Panayiota, Paul van den Broek, Mary Jane White \& Julie Lynch. 2007. Preschool and early elementary comprehension: Skill development and strategy interventions. In D.S. McNamara (ed.) Reading Comprehension Strategies: Theories, Interventions and Technologies.

Lang, Christian, Roman Schneider, Horst Schwinn, Karolina Suchowolec \& Angelika Wöllstein (Hrsg.). 2020. Grammatik und Terminologie. Tübingen: Narr. (In German).

Lyashevskaya, Ol'ga \& Egor Kashkin. 2015. FrameBank: A Database of Russian Lexical Constructions. In Khachay M., Konstantinova N., Panchenko A., Ignatov D. \& Labunets V. (eds.) Analysis of Images, Social Networks and Texts. AIST 2015. Communications in Computer and Information Science, 542. Springer, Cham. DOI: https://doi.org/10.1007/ 978-3-319-26123-2_34.

McCarthy, Kathryn S., Danielle S. McNamara \& Marina. I. Solnyshkina, Fanuza Kh. Tarasova \& Roman V. Kupriyanov. 2019. The Russian Language Test: Towards Assessing Text Comprehension. Vestnik Volgogradskogo gosudarstvennogo universiteta. Seriya 2. Yazykoznanie (Science Journal of Volgograd State University. Linguistics) 18 (4). 231-247. DOI: https://doi.org/10.15688/jvolsu2.2019.4.18.

McNamara, Danielle S. 2001. Reading both high-coherence and low-coherence texts: Effects of text sequence and prior knowledge. Canadian Journal of Experimental Psychology 55 (1), 51-62. DOI: 10.1037/h0087352.

McNamara, Danielle S., Eileen Kintsch, Nancy Butler Songer \& Walter Kintsch. 1996. Are good texts always better? Interactions of text coherence, background knowledge, and levels of understanding in learning from text. Cognition and Instruction 14 (1). 1-43.

McNamara, Danielle S. \& Joe P. Magliano. 2009. Towards a comprehensive model of comprehension. In B. Ross (ed.) The Psychology of Learning and Motivation. New York, NY: Academic Press, 51, 297-384. DOI: 10.1016/S0079-7421(09)51009-2.

Mustajoki, Arno. 2012. A Speaker-oriented Multidimensional Approach to Risk and Causes of Miscommunication. Language and Dialogue 2 (2). 216-243.

Petrova, Anna A. \& Larisa N. Rebrina 2016. Autobiographical memory: genesis, functioning, discursive implementation. Xlinguae 9 (2). 11-36. (In Russ.). DOI: 10.18355/XL.2016. 09.02.11-36.

Solovyev, Valery D., Marina I. Solnyshkina, Elzara V. Gafiyatova, Danielle S. McNamara \& Vladimir V. Ivanov. 2019. Sentiment in Academic Texts. Proceedings of the 24th Conference of Open Innovations Association (FRUCT). 408-414. DOI: 10.23919/ FRUCT.2019.8711900.

Solovyev, Valery D., Marina I. Solnyshkina \& Vladimir V. Ivanov 2019. Prediction of reading difficulty in Russian academic texts. Journal of Intelligent \& Fuzzy Systems 36 (5). 4553-4563. DOI: 10.3233/JIFS-179007.

\section{Словари и интернет-ресурсы / Dictionaries and Internet Resources}

Интегративный тест тревожности [Электронный pecypc]. URL: https:/psylab.info/ Интегративный_тест_тревожности (дата обращения: 24.01.2021). [Integrativnyj test trevozhnosti (Integrative Anxiety Test)]. Retrieved from https://psylab.info/ Интегративный_тест_тревожности (accessed 24 January 2021).

Русский семантический словарь. IV. Толковый словарь, систематизированный по классам слов и значений / отв. ред. Н.Ю. Шведова. М.: РАН, Ин-т рус. яз., 2007. 952 с. [Russkij semanticheskij slovar'. IV. Tolkovyj slovar', sistematizirovannyj po klassam slov i znachenij (Russian semantic dictionary. IV. Explanatory dictionary, systematized by classes of words and meanings). N.Ju. Shvedova (ed.). 2007. Moscow: RAN, In-t rus. jaz. (In Russ.)]. 
Тест интеллекта Векслера / детский вариант (6,5-16,5 лет) [Электронный ресурc]. URL: https://www.dbglab.ru/slovar-dannykh/221/ (дата обращения: 24.01.2021). [Test intellekta Vekslera/detskij variant (6,5-16,5 let) (Wexler Intelligence Test / children's version (6.5-16.5 years old))]. Retrieved from https://www.dbglab.ru/slovar-dannykh/ 221/ (accessed 24 January 2021).

Экспериментальный синтаксический словарь / под ред. Л.Г. Бабенко [Электронный реcypc] URL: https://www.slovari.ru/default.aspx?s=0\&p=2847 (дата обращения: 04.08.2020). [Jeksperimental'nyj sintaksicheskij slovar' (Experimental Syntax Dictionary)]. L.G. Babenko (ed). Retrieved from https://www.slovari.ru/default.aspx?s= $0 \& p=2847$ (accessed 4 August 2020).

FRAMEBANK [Электронный ресурс]. Retrieved from https://framenet.icsi.berkeley.edu/ fndrupal/framenets_in_other_languages (accessed 15 June 2020).

\section{Article history:}

Received: 10 September 2020

Accepted: 22 January 2021

\section{История статьи:}

Дата поступления в редакцию: 10 сентября 2020

Дата принятия к печати: 22 января 2021

\section{Bionotes:}

Anna A. PETROVA is Doctor habil. of Philology, Associate Professor, Leading Research Fellow of the "Intellectual Technologies for Text Management" Research Laboratory at Kazan (Volga Region) Federal University. Her research interests embrace psycholinguistics, sociolinguistics, discourse analysis, ontolinguistics, prosody of speech, multimodality and cognitology.

\section{Contact information:}

Kazan (Volga Region) Federal University, 18 Kremlevskaya St., Kazan, Russia, 420008 e-mail: petrova16@mail.ru

ORCID: 0000-0003-4322-1324

Marina I. SOLNYSHKINA is Doctor habil. of Philology, Professor at the Department of Theory and Practice of Foreign Languages Teaching, Chief Researcher and Head of the "Intellectual Technologies for Text Management" Research Laboratory at Kazan (Volga Region) Federal University. Her research interests include psycholinguistics, cognitive linguistics, discourse analysis, applied linguistics, lexicography and sociolinguistics.

\section{Contact information:}

Kazan (Volga Region) Federal University, 18 Kremlevskaya St., Kazan, Russia, 420008 e-mail: mesoln@yandex.ru

ORCID: 0000-0003-1885-3039

\section{Сведения об авторах:}

Анна Александровна ПЕТРОВА - доктор филологических наук, доцент, ведущий научный сотрудник НИЛ «Интеллектуальные технологии управления текстами» Казанского (Приволжского) федерального университета. В сферу ее научных интересов входят: психолингвистика, социолингвистика, анализ дискурса, онтолингвистика, просодия речи, мультимодальность, когнитология. 


\section{Контактная информация:}

Казанский (Приволжский) федеральный университет

Россия, 420008, г. Казань, ул. Кремлевская, 18

e-mail: petrova16@mail.ru

ORCID: 0000-0003-4322-1324

Марина Ивановна СОЛНЫШКИНА - доктор филологических наук, профессор кафедры теории и практики преподавания иностранных языков, руководитель и главный научный сотрудник НИЛ «Интеллектуальные технологии управления текстами» Казанского (Приволжского) федерального университета. Сфера ее научных интересов включает психолингвистику, когнитивную лингвистику, анализ дискурса, прикладную лингвистику, лексикографию и социолингвистику.

\section{Контактная информация:}

Казанский (Приволжский) федеральный университет

Россия, 420008, г. Казань, ул. Кремлевская, 18

e-mail:mesoln@yandex.ru

ORCID: 0000-0003-1885-3039 